\title{
Павлова Е.В. \\ Проблемные аспекты, возникающие на стадии судебного разбирательства административного правонарушения мелкое хулиганство
}

Орловский юридический институт МВД России имени В.В. Лукьянова (Россия, Орел)

doi: 10.18411/lj-04-2021-242

\section{Аннотация}

Предметом настоящего исследования является система общественных и правовых отношений при организации судебного разбирательства административных правонарушений мелкое хулиганство. Объектом исследования выступили общественные отношения, возникающие в сфере деятельности государственных органов и их должностных лиц при реализации судебного разбирательства мелкое хулиганство. Автор останавливается на детальном изучении действующих правовых норм, а также проблемных аспектов, возникающих при квалификации мелкого хулиганства и его доказывании.

Ключевые слова: административное правонарушение, мелкое хулиганство, нормативное толкование, умысел.

\section{Abstract}

The subject of this study is the system of public and legal relations in the organization of the trial of administrative offenses of minor hooliganism. The object of the study was the public relations that arise in the sphere of activity of state bodies and their officials during the implementation of the trial of minor hooliganism. The author focuses on a detailed study of the current legal norms, as well as the problematic aspects that arise in the qualification of minor hooliganism and its proof.

Keywords: administrative offense, misdemeanor hooliganism, normative interpretation, intent.

Среди дел об административных правонарушениях, подведомственных судам, большой процент составляют те, что посягают на общественный порядок и общественную безопасность. Наиболее распространено среди них мелкое хулиганство. Рассмотрение дел указанной группы у судов не инициирует больших проблем на сегодняшний день, однако вопросы, требующие осмысления, все же остаются.

Известно, что подготовка к рассмотрению дела включает составление протокола об административном правонарушении. По ст. 20.1 КоАП РФ [1] такой компетенцией наделены должностные лица органов внутренних дел. Перечень должностных лиц, уполномоченных составлять протоколы по мелкому хулиганству, не так давно претерпел изменения и утвержден новым приказом МВД России.

Рассмотрение таких дел от имени полиции на текущий момент возложено на определенный законом круг руководителей, их заместителей, а также должностных лиц, которые установлены ч. 2 ст. 23.3 КоАП РФ.

По ст. 20.1 КоАП РФ кроме штрафа может назначаться такая мера ответственности, как административный арест. При этом выделяются два важных условия: с одной стороны, это - исключительность подобных случаев, с другой - право применения только судом в соответствии с ч. 1 ст. 3.9 КоАП РФ.

При таком развитии нормативного толкования стадия рассмотрения дел о мелком хулиганстве переходит в компетенцию суда только в случае вынесения уполномоченным должностным лицом соответствующего определения (о передаче дела судье, наделенному правом применять иной вид или размер санкции на основании п. 1 ч. 2 ст. 29.9 КоАП РФ). В ситуации, когда орган или должностное лицо посчитало необходимым применить меру наказания в виде административного ареста и в связи с 
этим реализовало предоставленную возможность передать дело о мелком хулиганстве суду, последний теряет собственную инициативу и обязан принять такое дело к рассмотрению [2].

Вместе с тем отмечается, что суды не всегда соблюдают эти правила. Случается, что протоколы об административных правонарушениях, предусмотренных ст. 20.1 КоАП РФ, со всеми материалами принимаются судами без определений о передаче дела им на рассмотрение. Следовательно, возникает ситуация, при которой суд обязан инициировать дальнейшее производство используя собственную инициативу.

Отталкиваясь от сути толкования п. 1 ч. 2 ст. 29.9, а также ст. 29.12 КоАП РФ, органы и должностные лица по результатам рассмотрения дела обязаны вынести мотивированное решение и оформить его в виде определения. Такое определение должно приниматься судом в качестве необходимого условия для рассмотрения всех материалов дела о мелком хулиганстве и доведения его до логического завершения.

При этом результаты проводимых исследований дел о мелком хулиганстве демонстрируют отрицательную тенденцию. С каждым годом со стороны органов и должностных лиц увеличивается количество случаев, когда определения о передаче дела на рассмотрение суду выносятся с нарушением правил, установленных законом. Выражается данный факт в упрощении содержания текстов определений. Все может быть сведено лишь к формулировке самого факта направления материалов дела в суд. Не получают должных аргументов причины, на основании которых дела о мелком хулиганстве переданы в компетенцию суда. Отсутствует описание мотивов, подтверждающих невозможность назначить другую санкцию, кроме применения в отношении лица, совершившего мелкое хулиганство, административного наказания в виде ареста. Стоит отметить, что не допускается в качестве достаточного основания для передачи дела на рассмотрение суду сам факт описания сути объективной стороны правонарушения в определении.

В таких случаях очевидным становится нарушение п. 1 ч. 2 ст. 29.9 КоАП РФ. Учитывая повышенную строгость административного ареста в сравнении с другими санкциями за совершение мелкого хулиганства, а также особенность преодоления сроков, сокращаемых применительно к стадии рассмотрения, становится необходимым осуществлять подробную мотивировку определения о передаче дела по подведомственности суду.

Рассмотренные выше ошибки судами исправляются не всегда.

Дела о мелком хулиганстве в таких условиях не должны быть приняты судом. Ситуация обязывает возвращать материалы дела тому органу или должностному лицу, которое в соответствии с п. 4 ч. 1 ст. 29.4 КоАП РФ, составило протокол об административном правонарушении. В противном случае решение суда о применении в отношении мелкого хулигана санкции в виде административного ареста становится невозможным [3].

Неоправданная передача дел об административных правонарушениях, предусмотренных ст. 20.1 КоАП РФ, в компетенцию суда может быть обусловлена также другими обстоятельствами субъективного характера.

При необходимости применить в качестве меры ответственности административный арест в присутствии лица, в отношении которого возбуждено производство по делу, составляется протокол. Данный процессуальный документ по правилам, установленным ст. 28.2 и ч. 2 ст. 28.8 КоАП РФ, должен быть немедленно отправлен в суд для рассмотрения. В таком случае присутствие лица, в отношении которого рассматривается дело о мелком хулиганстве, становится обязательным. Об этом прямо указано в ч. 3 ст. 25.1 КоАП РФ.

Вместе с тем трактовка ч. 2 ст. 28.8 КоАП РФ позволяет утверждать, что обеспечить явку привлекаемого к ответственности лица, является полномочием того субъекта, который передает дело по подведомственности в суд. Здесь необходимо обратить внимание на условие, закрепленное в ч. 4 ст. 29.6 КоАП РФ. В соответствии с 
ним дело должно быть рассмотрено судом в день его поступления. Следовательно, за обеспечение явки правонарушителя в суд отвечают именно органы внутренних дел.

Другая группа проблем, возникающих у судей при рассмотрении дел о мелком хулиганстве, характеризуется ошибками в квалификации данного деяния. Зачастую должностные лица в протоколе об административном правонарушении допускают формулировки, которые указывают на очевидные ошибки квалификации, к примеру, такие, как «учинил бытовой конфликт, чем выражал явное неуважение к обществу». Обращает на себя внимание отсутствие в протоколах описания самого события мелкого хулиганства, что рассматривается как нарушение требований ч. 2 ст. 28.2 КоАП РФ. Или такой пример: «...дал личные объяснения о том, что после употребления алкоголя с друзьями вернулся к себе в квартиру, где закатил скандал в ответ на истерику матери, которая вызвала сотрудников полиции». Объяснения в данном случае демонстрируют как сын, находясь в состоянии алкогольного опьянения, устроил конфликт на бытовой почве со своей матерью. При этом с его стороны допускалась нецензурная брань и игнорировались требования матери прекратить скандал. Представленная ситуация указывает на отсутствие мотивов, на основании которых суд сделал заключение о наличие в событии состава мелкого хулиганства. В частности, не уточнены такие важные квалифицирующие признаки, как совершение деяния в общественном месте, не указано, в чем конкретно заключено нарушение общественного порядка, то есть не раскрывается само действие, выражающее явное неуважение к обществу[4].

Мелкое хулиганство - это действия, которым характерен умысел. Направленность такого умысла имеет цель для виновного - нарушить правила, соответствующие общественному порядку. При этом поступки должны отражать очевидное, фактическое желание лица противопоставить себя окружающим и обществу. Действия являются назойливыми, досаждающими окружающим лицам, унижающими их личное достоинство, дерзкими по своей форме, сопровождающимися бранью, содержащей нецензурную лексику. К этому стоит добавить повреждение или уничтожение принадлежащего потерпевшим лицам имущества.

Продолжая рассматривать ранее изложенную ситуацию, нельзя не отметить, что совершались они в квартире на основе отношений личного неприязненного характера между членами одной семьи.

Лица, проживающие в соседних квартирах, беспокойства по данному поводу не испытывали, о чем говорит отсутствие с их стороны каких-либо претензий. На первый взгляд, главный признак - совершение деяния в общественном месте отсутствует, поэтому данное деяние не должно квалифицироваться как мелкое хулиганство.

Еще одним часто встречающимся недостатком, касающимся рассмотрения дел о мелком хулиганстве, является вопрос относимости и допустимости доказательств. На их основании суды формулируют описательно-мотивировочную часть своих постановлений, поэтому содержание мотивов для принятия будущего решения о назначении административного наказания должно подробно раскрываться, а не просто перечисляться в постановлении суда. В отношении свидетелей и потерпевших недостаточно просто указать их фамилии. Необходимо формулировать их показания подробно и развернуто. В случае выявления несоответствия между ними, суд обязан давать такому факту соответствующую оценку.

С определенной периодичностью фиксируются и факты необоснованного допуска судами в качестве доказательств письменных показаний свидетелей и потерпевших, полученных должностными лицами органов внутренних дел с нарушением закона. Например, недопустимо использовать показания лиц, которые не были предупреждены об ответственности за дачу заведомо ложных показаний на основании ст. 17.9 КоАП РФ. Для проверки подлинности и правдивости фактов, указанных в протоколе об административном правонарушении, в том случае, если имеются основания для соответствующих подозрений, суд вызывает этих лиц и по возможности на месте устраняет допущенные процессуальные нарушения. 
Таким образом, следует отметить, что в условиях реформирования законодательства об административных правонарушениях необходимо новое теоретическое осмысление проблем правоприменительной практики и правовой регламентации конкретных стадий производства по делам о мелком хулиганстве и определения приоритетных направлений совершенствования деятельности как должностных лиц, так и судей, участвующих в рассмотрении таких дел.

$$
* * *
$$

1. Кодекс Российской Федерации об административных правонарушениях Федеральный закон от 30 декабря 2001 г. № 195-Ф3 // Справочно-правовая система «КонсультантПлюс»: [Электронный pecypc] http://www.consultant.ru. (дата обращения 06.01.2021)

2. Кивич Ю.В. Проблемы, возникающие при рассмотрении судами дел о мелком хулиганстве // В сборнике: Конституционное и административное право: проблемы совершенствования публичной власти. Сборник научных трудов участников Международной научно-теоретической конференции. 2018. С. 98-104.

3. Светличная Т.Б., Слюсарева Т.Г. Проблемные вопросы административной ответственности за мелкое хулиганство // Пробелы в российском законодательстве. 2018. № 6. С. 297-300.

4. Постановление Кировского районного суда г. Кемерово по делу № 5-4/2017 от 05.01.2017 г. // [Электронный pecypc] https://sud-praktika.ru (Дата обращения 06.01.2021)

\section{Портянко Е.М. \\ Портрет детоубийцы. Убийство матерью новорожденного ребёнка: криминологическая характеристика}

Дальневосточный Федеральньй университет

(Россия, Владивосток)

doi: 10.18411/lj-04-2021-243

\section{Аннотация}

В статье анализируются статистические данные по количеству зарегистрированных убийств матерью новорожденного ребенка. Рассматривается криминологический портрет женщин-детоубийц. Особое внимание уделяется их социально-демографическим характеристикам. Выделяются внешние обстоятельства, выступающие в роли причин, которые толкают женщин на убийство своего новорожденного ребенка.

Ключевые слова: мать-убийца, новорожденный, статистические данные, криминологическая характеристика, социально-демографические признаки, причины убийства новорожденного.

\section{Abstract}

The article analyzes statistical data on the number of recorded murders by the mother of a newborn child. A criminological portrait of female child murderers is considered. Special attention is paid to their socio-demographic characteristics. External circumstances stand out that play the role of reasons that push women to kill their newborn baby.

Keywords: mother-killer, newborn, statistical data, criminological characteristics, socio-demographic signs, causes of killing a newborn.

Актуальность вопроса борьбы с убийствами матерью новорожденного ребенка подтверждает статистика распространения детоубийства в РФ. Так, согласно официальной статистике Генеральной прокуратуры Российской Федерации за 2010 2020 гг. было зарегистрировано 1162 преступлений, квалифицированных по статье 106 УК РФ (рис.1).

Несмотря на явную тенденцию к снижению ситуация остается неблагоприятной. 